\title{
The Perception of Teleworking by University Students Before and During the COVID-19 Crisis
}

\author{
Tomas Sigmund ${ }^{1, *}$, Pavel Sladek ${ }^{2}$ \\ ${ }^{1}$ University of Economics, Prague, Faculty of Informatics and Statistics, Department of System \\ Analysis, nam. W. Churchilla 1938/4, 13067 Praha 3, Czech Republic \\ ${ }^{2}$ Institute of Technology and Business in Ceske Budejovice (Vysoka skola technicka a ekonomicka v \\ Ceskych Budejovicich), Okruzni 517/10, 37001 Ceske Budejovice, Czech Republic
}

\begin{abstract}
.
Research background: Teleworking is becoming more current and more used. It is an instrument that allows and supports globalization. The corona crisis increased its use even more. Teleworking has advantages, but also disadvantages which are perceived and evaluated by its users. With its more intense penetration, the users' perception will become an important factor in the implementation. Teleworking has effects both on the whole economy and on the employees - it affects their social life, their working relations, and their flexibility.

Purpose of the article: The purpose of the article is to identify the students' perception of advantages and disadvantages of teleworking and the development of this perception from the year 2018 to the year 2020. In 2020 , the data were collected during and after the corona crisis, and so we can observe its effects.

Methods: We used an electronic survey to monitor students' opinion on teleworking and processed the data by methods of descriptive statistics and more advanced statistical methods to obtain their characteristics.

Findings \& Value added: We found out that the perception of teleworking's advantages and disadvantages didn't change much from the year 2018 and stayed relatively stable in spite of the crisis. Only some effects of teleworking were considered by our respondents a little differently, e.g., the social aspects. Our findings may be used in addressing the perceived disadvantages of teleworking and supporting its advantages.
\end{abstract}

Keywords: Teleworking; working relations; work/life balance; flexibility

JEL Classification: $J 22 ; J 24$

\footnotetext{
${ }^{*}$ Corresponding author: sigmund@,vse.cz
} 


\section{Introduction}

Various economic, technological and environmental pressures have caused changes in the design of employment. Flexibility is an important requirement since the nineties [1]. That is why companies have to use employment models which suit various workers and allow unconventional work methods.

Teleworking means a type of work where employees work from home instead of at the employer's premises. With teleworking, it is easier to perform the work outside the standard working hours. Teleworking uses various technological devices, such as telephones, computers, notebooks etc. There are various models of teleworking. Employees don't have to work at home every day, but a few days may be spent at work and a few can be worked from home. Teleworking uses the opportunity offered by technologies consisting in flexible work location and removal of the limits imposed by one common workplace.

The societal changes also support the introduction of teleworking. The number of dual career families rises, number of employed women with children is also quite high (the employment of women with children 3-4 years of age increased from 54\% in 2010 to $72 \%$ in 2018 in the Czech Republic [2], the population is getting older which are all factors leading to the adoption of teleworking.

Teleworking is related job insecurity and uncertainty. It can also negatively affect career opportunities because of lack of personal contact and real presence in the workplace, no out of work relations etc. It is sometimes called the "out-of sight - out-of-mind" syndrome.

Commitment to work which is defined as an identification with and involvement in an organization helps in the introduction of teleworking. Committed employees are ready to use new work practices including teleworking.

As teleworkers must rely on themselves more, it is necessary to offer them some support of technical and managerial kind. Understanding, concern and acceptance are important in positive approaches towards teleworking [3]. Supervisors should support teleworking and appreciate teleworkers.

Teleworking is not identical with classical work, it has its advantages and disadvantages. It allows more time and space flexibility and autonomy in work. That may lead to higher job satisfaction. Employees working on the distance may schedule their time more easily, they can take care of their children, old parents or disabled family members. They get also more time for their leisure activities. They save some commuting time which has positive effects on the stress level, physical and mental health. [4]. Traffic congestion are very common.

Teleworking can be connected to increased productivity [5]. Teleworkers are less interrupted, can better concentrate, have more energy due to reduced commuting. Teleworking allows working on hours when the employee is most productive.

The most reported disadvantages of teleworking include problems with career, limited interaction with colleagues, lower frequency of social contacts, disengagement, lack of the sense of belonging [6]. Separation from colleagues may cause stress and lower working morale. There is no exchange of ideas between workers.

Another problem is related to the sense of lower privacy and control over the workplace in the employer's premises. A consequence of teleworking may be the lower demand for workspace that may lead to shared workspaces. And the consequence of that may be lower sense of privacy.

For companies teleworking brings savings in reduced offices required, lower demand for parking space. They can also recruit employees regardless of their residence. For some employees teleworking is the reason why they retain with the company [4].

The disadvantages of teleworking for companies include difficult supervisor, control and appraisal of employees. Some problems are related to data security as any break down 
or leakage leads to harms in the company's competitiveness. Problems with repairs and maintenance may also arise.

\section{Working from home: characteristics and outcomes of telework}

Telework offers the opportunity to work anywhere and anytime. It may be considered a win-win alternative as it reduces costs, improves motivation, allows employees to organize their workloads and supports family relations.

The advantages for employees include planning freedom [7], autonomy [8], lower stress [9], higher productivity [10], job satisfaction [11], reduced commuting [12], better and wider job opportunities for disadvantaged social groups, lower pollution due to reduced traffic. On the other hand teleworking has also challenges for employees. There is a lack of face to face communication and social interaction between employees, it is more difficult to arise awareness of organizational values, and teleworkers may feel less support from the management [13]. Some teleworkers claim that their less frequent presence at the workplace reduces their career opportunities [14].

Teleworking allows the worker to organize his time better and to support the work-life balance. However, teleworker is exposed to interruptions, can be tempted to work longer or at weekends which may harm his work-life balance. The combination of work and familyrelated activities represents a challenge for the teleworker.

In teleworking we can differentiate its intensity - there are both full-time, part-time and ad hoc telework models, time when it is performed - teleworker can work either in traditional working hours or spend evenings or weekends working and its place - there are multisite telework models or freelance telework if the teleworker has an agreement with more employer or mobile telework if the work is done on many different sites or just work from home of the teleworker works from home for one employer.

In spring 2020 the battle against COVID-19 started in Europe and the movement of workers which are not essential for the economy was halted. For many companies the only way how to survive was to transfer their employees on work from home. That is why we researched the perception of teleworking during the crisis and compared it with the results we collected before the crisis.

In Table 1 we can see that teleworking has been becoming more popular in Europe since the nineties. In 2018 13.5\% of persons employed aged between 15 and 64 worked remotely in EU-28.

Table 1. Percentage of persons employed aged 15 to 64 who telework, (Eurostat, Labour Force

\begin{tabular}{|l|l|}
\hline Netherlands & $38,4 \%$ \\
\hline Sweden & $33,1 \%$ \\
\hline Finland & $29,7 \%$ \\
\hline Denmark & $29,1 \%$ \\
\hline Luxembourg & $28,7 \%$ \\
\hline UK & $23,9 \%$ \\
\hline Belgium & $22,8 \%$ \\
\hline Austria & $21,7 \%$ \\
\hline France & $20,8 \%$ \\
\hline Estonia & $20,2 \%$ \\
\hline Ireland & $19,7 \%$ \\
\hline Slovenia & $18,3 \%$ \\
\hline Portugal & $14,7 \%$ \\
\hline
\end{tabular}




\begin{tabular}{|l|c|}
\hline Poland & $14,0 \%$ \\
\hline Germany & $11,6 \%$ \\
\hline Malta & $9,8 \%$ \\
\hline Czech Republic & $9,4 \%$ \\
\hline Slovakia & $9,1 \%$ \\
\hline Spain & $7,5 \%$ \\
\hline Croatia & $6,7 \%$ \\
\hline Hungary & $6,0 \%$ \\
\hline Greece & $5,1 \%$ \\
\hline Italy & $4,8 \%$ \\
\hline Latvia & $4,8 \%$ \\
\hline Lithuania & $4,6 \%$ \\
\hline Cyprus & $2,2 \%$ \\
\hline Bulgaria & $0,9 \%$ \\
\hline Romania & $0,7 \%$ \\
\hline
\end{tabular}

The use of teleworking in European countries in the past ten years has been increased by 3 percent between 2009 and 2018. Early estimates from Eurofond [15] lead to the conclusion that almost $40 \%$ of workers began to use teleworking as a consequence of the COVID-19 pandemic. Before the COVID crisis only $15 \%$ of workers had an experience with teleworking. The European Commission in its 2020 communication claims that teleworking is important for the jobs and production preservation [16].

According to the Eurostat Study (2018) in the Czech Republic more women $(4,6 \%)$ than men $(3,3 \%)$ usually work from home. The Eurostat suggested that in 2017 1,3\% of 15-24 year old employees worked regularly from home, $3,7 \%$ of $25-49 \%$ years old and $5,4 \%$ of 50-74 years old. The older the workers the more they tend to use teleworking [17].

\section{Materials and Methods}

In our research we focused on the university students. We compared their answers to identical questions collected in years 2018 and 2019 with those collected during the COVID-19 crisis and lock down in the spring 2020. The first set (Data set I) of answers was receive continually through from $1^{\text {st }}$ Octobre 2018 till the end of the year 2019. The second data set (Data set II) was collected from 8the April till 30 ${ }^{\text {th }}$ April 2020. We used the Google form and send an email to students with the link to the questionnaire. The students were from the Technical and Economic University (VŠTE) and Economic university (VŠO). The gender composition of the two dataset can be found in Table 2 and 3.

Table 2. Data set I

\begin{tabular}{|c|c|c|}
\hline & Frequency & Percent \\
\hline Men & 52 & 41,9 \\
\hline Women & 72 & 58,1 \\
\hline Total & 124 & 100,0 \\
\hline
\end{tabular}

Table 3. Data set II

\begin{tabular}{|l|r|r|}
\hline & Frequency & Percent \\
\hline Men & 39 & 25,2 \\
\hline Women & 116 & 74,8 \\
\hline Total & 155 & 100,0 \\
\hline
\end{tabular}


We used the six point Likert scale in most answers with 1 meaning definitely no, and 6 meaning definitely yes.

We concentrated on some general questions related to teleworking. In these questions only the options "yes" (1) or "no" (2) were possible.

1) Do you know the concept of teleworking?

2) Do you use teleworking in your work?

3) Would you like to work on a distance?

Then, we focused on the advantages and disadvantages of teleworking for the worker.

The advantages were:

4) I don't have to commute to work.

5) With teleworking, I can perform the type of work I couldn't perform offline.

6) With teleworking I have more freedom.

7) I can organize and plan the work myself.

8) I will save some money.

The disadvantages were:

9) My boss wants me to work more.

10) I can't separate free time and work.

11) There is a conflict between working life and family life.

12) I miss the natural human communication.

13) I feel isolated.

14) This type of work is too expensive for me.

15) I can't influence the situation and resolutions in the company.

16) The possibility of promotion is limited.

17) I get less money.

Finally, the pros and contras of teleworking from the social perspective were discussed.

Advantages:

18) Higher labour supply on the labour market

19) Lower traffic

20) Qualified people can live outside of city centres.

Disadvantages:

21) Depopulation of city centres

22) Psychological and physiological problems

\section{Results}

When summarising the results we used the statistical measures of mean and standard deviation. The results can be found in Tables 4, 5, 6, 7 and 8. The bigger differences between years 2018-2019 and 2020 were marked grey in the tables. The questions in the tables deal with various categories of teleworking advantages and disadvantages.

Table 4. Results I (M-mean; SD-standard deviation)

\begin{tabular}{|l|l|l|}
\hline General questions & $2018-2019$ & 2020 \\
\hline 1) Do you know the concept of teleworking? & $\mathrm{M}=1,41 ; \mathrm{SD}=0,494$ & $\mathrm{M}=1,19 ; \mathrm{SD}=0,39$ \\
\hline 2) Do you use teleworking in your work? & $\mathrm{M}=1,87 ; \mathrm{SD}=0,337$ & $\mathrm{M}=1,74 ; \mathrm{SD}=0,44$ \\
\hline 3) Would you like to work on a distance? & $\mathrm{M}=1,38 ; \mathrm{SD}=0,487$ & $\mathrm{M}=1,35 ; \mathrm{SD}=0,48$ \\
\hline
\end{tabular}

Table 5. Results II

\begin{tabular}{|l|l|l|}
\hline $\begin{array}{l}\text { Teleworker's perspective } \\
\text { Advantages: }\end{array}$ & $2018-2019$ & 2020 \\
\hline 4) I don't have to commute to work. & $\mathrm{M}=4,5 ; \mathrm{SD}=1,36$ & $\mathrm{M}=4,56 ; \mathrm{SD}=1,25$ \\
\hline 5) With teleworking, I can perform the type of & $\mathrm{M}=3,58 ; \mathrm{SD}=1,13$ & $\mathrm{M}=3,51 ; \mathrm{SD}=1,44$ \\
\hline
\end{tabular}




\begin{tabular}{|l|l|l|}
\hline work I couldn't perform offline. & & \\
\hline 6) With teleworking I have more freedom. & $\mathrm{M}=4,74 ; \mathrm{SD}=1,18$ & $\mathrm{M}=4,76 ; \mathrm{SD}=1,29$ \\
\hline 7) I can organize and plan the work myself. & $\mathrm{M}=4,79 ; \mathrm{SD}=1,26$ & $\mathrm{M}=4,99 ; \mathrm{SD}=1,17$ \\
\hline 8) I will save some money. & $\mathrm{M}=4,37 ; \mathrm{SD}=1,2$ & $\mathrm{M}=4,35 ; \mathrm{SD}=1,24$ \\
\hline
\end{tabular}

Table 6. Results III

\begin{tabular}{|l|l|l|}
\hline $\begin{array}{l}\text { Teleworker's perspective } \\
\text { Disadvantages: }\end{array}$ & $2018-2019$ & 2020 \\
\hline 9) My boss wants me to work more. & $\mathrm{M}=3,06 ; \mathrm{SD}=1,13$ & $\mathrm{M}=3,05 ; \mathrm{SD}=1,33$ \\
\hline 10) I can't separate free time and work. & $\mathrm{M}=3,93 ; \mathrm{SD}=1,2$ & $\mathrm{M}=3,69 ; \mathrm{SD}=1,59$ \\
\hline $\begin{array}{l}\text { 11) There is a conflict between working life and } \\
\text { family life. }\end{array}$ & $\mathrm{M}=3,57 ; \mathrm{SD}=1,21$ & $\mathrm{M}=3,17 ; \mathrm{SD}=1,51$ \\
\hline 12) I miss the natural human communication. & $\mathrm{M}=3,76 ; \mathrm{SD}=1,39$ & $\mathrm{M}=4,34 ; \mathrm{SD}=1,38$ \\
\hline 13) I feel isolated. & $\mathrm{M}=3,65 ; \mathrm{SD}=1,44$ & $\mathrm{M}=4,16 ; \mathrm{SD}=1,45$ \\
\hline 14) This type of work is too expensive for me. & $\mathrm{M}=2,41 ; \mathrm{SD}=1,08$ & $\mathrm{M}=1,95 ; \mathrm{SD}=0,95$ \\
\hline $\begin{array}{l}\text { 15) I can't influence the situation and } \\
\text { resolutions in the company. }\end{array}$ & $\mathrm{M}=3,73 ; \mathrm{SD}=1,12$ & $\mathrm{M}=3,41 ; \mathrm{SD}=1,27$ \\
\hline 16) The possibility of promotion is limited. & $\mathrm{M}=3,47 ; \mathrm{SD}=1,04$ & $\mathrm{M}=3,43 ; \mathrm{SD}=1,39$ \\
\hline 17) I get less money. & $\mathrm{M}=2,92 ; \mathrm{SD}=1,09$ & $\mathrm{M}=2,93 ; \mathrm{SD}=1,42$ \\
\hline
\end{tabular}

Table 7. Results IV

\begin{tabular}{|l|l|l|}
\hline $\begin{array}{l}\text { Social perspective } \\
\text { Advantages: }\end{array}$ & $2018-2019$ & 2020 \\
\hline 18) Higher labour supply on the labour market & $\mathrm{M}=3,73 ; \mathrm{SD}=1,05$ & $\mathrm{M}=3,94 ; \mathrm{SD}=1,23$ \\
\hline 19) Lower traffic & $\mathrm{M}=4,0 ; \mathrm{SD}=1,34$ & $\mathrm{M}=4,59 ; \mathrm{SD}=1,19$ \\
\hline $\begin{array}{l}\text { 20) Qualified people can live outside of city } \\
\text { centres. }\end{array}$ & $\mathrm{M}=3,63 ; \mathrm{SD}=1,11$ & $\mathrm{M}=4,0 ; \mathrm{SD}=1,27$ \\
\hline
\end{tabular}

Table 8. Results V

\begin{tabular}{|l|l|l|}
\hline $\begin{array}{l}\text { Social perspective } \\
\text { Disadvantages: }\end{array}$ & $2018-2019$ & 2020 \\
\hline 21) Depopulation of city centres & $\mathrm{M}=3,4 ; \mathrm{SD}=1,22$ & $\mathrm{M}=3,9 ; \mathrm{SD}=1,31$ \\
\hline 22) Psychological and physiological problems & $\mathrm{M}=2,83 ; \mathrm{SD}=1,2$ & $\mathrm{M}=2,97 ; \mathrm{SD}=1,23$ \\
\hline
\end{tabular}

\section{Discussion}

We can see that the difference between the two columns is not very big. Students seem to use teleworking more in 2020 (25,2\% compared to $12,9 \%)$. The percentage of students working remotely is above the average in the Czech Republic and achieves the level of western European countries.

As for the questions, the biggest difference can be found in questions 11, 13, 14, 15, 19 and 21. The results were independent on gender and age. Except for questions 16 and 17 where students seem to consider the disadvantages of teleworking less important, students are more sensitive towards personal advantages of teleworking (q. 11, 13, 19) and social advantages and disadvantages of it (q. 19-20). We can conclude that the difference can be explained by their practical experience with teleworking. They think they can organize the work themselves better, they seem to be more experienced and know how to separate work and free time, there are fewer conflicts between work and family. On the other hand they miss human communication more, feel more isolated, teleworking is less expensive for them than work in the employer's premises and are not so much persuaded that they can't 
influence the company's operations when teleworking. The social advantages are more appraised, but the social disadvantages as well. It seems they have better skills in managing teleworking, but its psychological and social aspects play a more important role for them.

Surprisingly, in spite of the coronavirus crisis and the lockdown the percentage of students using teleworking was not so high. That may be explained by the fact that not all students have a job or work just part time and during the crisis they were substituted by regular employees or their work was not necessary. Their evaluation of the advantages and disadvantages of teleworking doesn't differ so much, maybe because they new the advantages and disadvantages well before the crisis or were at least good informed about them and the lockdown didn't change their opinions.

\section{Conclusion}

We may conclude that use teleworking quite a lot and know its advantages and disadvantages. As for teleworking, they especially positively evaluate the freedom, ability to organise their life and cost savings.

The comparison of years 2018 and 2019 and the crisis time in 2020 shows students used teleworking more during the crisis, but their evaluation of the positives and negatives related to it didn't change much. Students are sensitive to the psychological and sociological effects of teleworking. The lack of natural human communication was perceived critically before the crisis and during it its perception became more important.

\section{References}

1. Hamblin, H. (1995). Employees' perspectives on one dimension of labour flexibility: working at a distance. Work, Employment and Society, 9(3), 473-498.

2. Mendlova, I. (2019). (Ne)zamestnanost v dobe „blahobytu”. Statistika a my, 17.1.2019. Retrieved from: https://www.statistikaamy.cz/2019/01/17/nezamestnanost-v-dobeblahobytu/.

3. Park, S., \& Cho, Y. J. (2020). Does telework status affect the behavior and perception of supervisors? Examining task behavior and perception in the telework context. The International Journal of Human Resource Management, 1-26.

4. Chung, H., van der Horst, M., (2020). Flexible Working and Unpaid Overtime in the UK: The Role of Gender, Parental and Occupational Status, Social Indicators Research, 151(2) 495-520.

5. Mahler, J. (2012). The telework divide: Managerial and personnel challenges of telework. Review of Public Personnel Administration, 32(4), 407-418.

6. Illegems, V., Verbeke, A., \& S'Jegers, R. (2001). The organizational context of teleworking implementation. Technological forecasting and social change, 68(3), 275291.

7. Johnson, L. C., Andrey, J., \& Shaw, S. M. (2007). Mr. Dithers comes to dinner: Telework and the merging of women's work and home domains in Canada. Gender, Place \& Culture, 14(2), 141-161.

8. Fonner, K. L., \& Roloff, M. E. (2010). Why teleworkers are more satisfied with their jobs than are office-based workers: When less contact is beneficial. Journal of Applied Communication Research, 38(4), 336-361. 
9. Golden, T. D., \& Veiga, J. F. (2008). The impact of superior-subordinate relationships on the commitment, job satisfaction, and performance of virtual workers. The Leadership Quarterly, 19(1), 77-88.

10. Bailey, D. E., \& Kurland, N. B. (2002). A review of telework research: Findings, new directions, and lessons for the study of modern work. Journal of Organizational Behavior: The International Journal of Industrial, Occupational and Organizational Psychology and Behavior, 23(4), 383-400.

11. Davidescu, A. A., Apostu, S. A., Paul, A., \& Casuneanu, I. (2020). Work Flexibility, Job Satisfaction, and Job Performance among Romanian Employees-Implications for Sustainable Human Resource Management. Sustainability, 12(15), 6086.

12. Hopkins, J. L., \& McKay, J. (2019). Investigating 'anywhere working'as a mechanism for alleviating traffic congestion in smart cities. Technological Forecasting and Social Change, 142, 258-272.

13. Maruyama, T., \& Tietze, S. (2012). From anxiety to assurance: Concerns and outcomes of telework. Personnel Review, 41(4), 450-469.

14. Harris, L. (2003). Home-based teleworking and the employment relationship: Managerial challenges and dilemmas, Personnel Review, 32(4), 422-437.

15. Eurofound. (2020). Living, working and COVID-19: First findings - April 2020. Online Retrieved from: https://www.eurofound.europa.eu/publications/report/2020/livi ng-working-and-covid-19-first-findings-april-2020.

16. European Commision. (2020). European Semester: Commission Communication on Country Specific Recommendations. Online Retrieved from: https://ec.europa.eu /info/publications/2020-european-semester-commission-communication-countryspecifi c-recommendationsen.

17. Jobspin. (2018). Eurostat: Fewer Czechs work from home compared to EU average. Retrieved from: https://www.jobspin.cz/2018/08/eurostat-fewer-czechs-work-fromhome-compared-to-eu-average/. 